\title{
PERSPEKTIF ORANG TUA DALAM GERAKAN PENUMBUHAN BUDI PEKERTI PADA MASA PANDEMI COVID 19
}

\author{
Fatahillah $^{\text {1)}}$, Septi Wulan Sari ${ }^{2)}$ \\ ${ }^{1)}$ FKIP, Universitas Muhammadiyah Pringsewu Lampung \\ ${ }^{2)}$ FKIP, Universitas Muhammadiyah Pringsewu Lampung \\ fatahillahpgsd@umpri.ac.id
}

\begin{abstract}
The government launched the "Movement of Character Development" which involved the roles of schools, parents, and the community. This movement should have been carried out well in normal times, but the Covid 19 pandemic around the world in which the government is carrying out a social investigation has closed school activities. The formulation of the research problems are 1) How do parents respond to the condition of character growth during this pandemic? 2) What are the views of the parents of students regarding the development of culture during this pandemic? The research method is qualitative research with a phenomenological tradition, both conducting remote interviews using WhatsApp facilities, Google Forms, and so on with parents. The results are 1) the response of the parents who responded: a) stuttering, b) just ordinary, and c) still confused about what happened so that a state of culture shock was created; 2) They expect assistance from all teachers, schools, communities and the government in assisting them to carry out learning activities during the Covid 19 period.
\end{abstract}

Keywords: character, learning, Covid 19

\section{PENDAHULUAN}

Budi Pekerti bagi manusia merupakan karakterisasi makhluk sosial yang lebih mulia dibandingkan makhluk hidup lain yang ada di muka bumi. Namun, pragmatisme telah mendominasi segala aspek kehidupan di tengah deraan kebutuhan ekonomi manusia yang kian hari semakin berat.

Budi Pekerti diterjemahkan sebagai tingkah laku, perangai, atau akhlak yang merujuk kepada nilai-nilai kebenaran norma dan moral pada satu masyarakat atau komunitas tertentu. Seperti apa yang digambarkan dalam Buku Terbitan Balai Pustaka (Tim Penyusun, 2012:3) Makna Budi Pekerti meliputi sikap Perilaku yang menjangkau 1) sikap dan perilaku dalam hubungan dengan Tuhan, 2) sikap dan perilaku dalam hubungannya dengan keluarga; 3) sikap dan perilaku dalam hubungannya dengan masyarakat dan bangsa; dan 4) sikap dan perilaku dalam hubungannya dengan masyarakat dan bangsa.

Peradaban itu bernilai baik atau tidak bergantung kepada budi pekerti yang diaplikasikan anggota sosial masyarakat di daerah tertentu. Widiastuti (2020:6-7) mengatakan budi pekerti dibentuk melalui dua faktor yakni; 1) Faktor 
formal yaitu pembentukan yang dilakukan melalui langkah-langkah usaha pendidikan dan pengajaran oleh lembaga atau institusi pendidikan formal dari Sekolah Dasar sampai Perguruan Tinggi, Sekolah Umum, Agama atau Sekolah Kejuruan; 2) Faktor informal merupakan pembentukan budi pekerti yang didapat dari sosialisasi primer dalam keluarga dan lingkungan berada. Budi pekerti terbentuk tidak hanya bergantung dari salah faktor saja akan tetapi keduanya harus dilakukan secara seimbang dan berkelanjutan.

Nilai positif dalam gerakan penumbuhan budi pekerti oleh Kementrian Pendidikan dan Kebudayaan Republik Indonesia (DIKDASMEN Kemendikbud RI, 2016: 20) adalah: 1) internalisasi sikap moral dan spiritual; 2) keteguhan menjaga semangat kebangsaan dan kebhinekaan untuk merekatkan persatuan dan kesatuan bangsa; 3) interaksi sosial positif antara peserta didik dengan orang tua, keluarga, dan lingkungan; 4) interaksi sosial positif antar peserta didik; 5) sikap yang perduli dengan lingkungan sekolah; 6) perhargaan terhadap keragaman; 7) penguatan peran orang tua, keluarga, dan masyarakat dalam mengembangkan sikap positif budi pekerti.

Penguatan peran orang tua dan keluarga penting diupayakan karena keluarga merupakan lingkungan pertama yang mempengaruhi berbagai aspek perkembangan anak terutama dalam rekayasa perilaku sebagai hasil dari sosialisasi primer. Rahmat (2018:152) menyatakan kepribadian anak ditentukan oleh keluarga dalam hal pengembangannya. Orang tua telah menetapkan hendak kemana atau pribadi seperti apa yang hendak dibentuk berdasarkan nilai-nilai norma yang berlaku dalam kehidupan keluarga. Apabila orang tua memiliki sikap pandangan religius, maka anak diharapkan memiliki sikap perilaku religius pula. Oleh karena itu, Kementrian Pendidikan Kebudayaan (KEMENDIKBUD RI, 2016:35) mengharapkan bentuk-bentuk keterlibatan orang tua di rumah. Keterlibatan orang tua di rumah antara lain menumbuhkan budi pekerti pada anak, menciptakan lingkungan rumah yang aman dan menyenangkan, serta mencegah dan menanggulangi kekerasan pada anak. Semua upaya itu dilakukan dengan langkahlangkah antara lain 1) mengembangkan interaksi positif antara peserta didik dengan guru dan orang tua. Hal tersebut dilakukan melalui upaya membangun persepsi positif, saling pengertian dan saling dukung. Saling pengertian dan saling 
dukung dilakukan melalui pertemuan antara guru dan orang tua. Pertemuan ini mensosialisasi visi, aturan, materi dan capaian pembelajaran siswa yang diharapkan dapat dukungan orang tua di rumah; 2) Melibatkan orang tua dan masyarakat di sekolah dengan mewujudkan nilai-nilai dalam perilaku sehari-hari. Hal tersebut dilakukan melalui pembiasan yang akhirnya membudaya.

Keefektifan pelaksanaan penumbuhan budi pekerti dalam belajar mengajar akan berlangsung dengan baik di tengah kondisi normal, tetapi pada pertengahan tahun 2020 merebak virus Covid 19 ke seluruh dunia termasuk Indonesia. Tercatat sudah 91.8 juta kasus Covid 19 meliputi 2 juta kasus meninggal dunia (http://covid19.go.id diakses tanggai 16 Januari 2021). Kondisi ini memaksa berbagai negara mengambil langkah-langkah untuk menahan laju penularannya. Salah satunya adalah karantina wilayah. Indonesia melaksanakan kebijakan untuk melakukan Pembatasan Sosial Berskala Besar (PSBB). Masyarakat dilarang untuk melakukan kerumunan yang melibatkan manusia dalam jumlah besar. Hal ini bertujuan agar menciptakan menjaga jarak berinteraksi sosial.

Kebijakan PSBB berimbas pada kegiatan belajar mengajar di Persekolahan yang diilustrasikan oleh Dewi (2020:57-59) dengan adanya Pandemi sekolah akan diarahkan untuk melakukan kegiatan-kegiatan pembelajaran yang bersifat daring melalui penggunaan alat-alat digital dan aplikasi-aplikasi berbasis Microsoft, Android, maupun IOS dan lain sebagainya seperti What's Up . Google Classroom, Zoom, Google Meet, dan lainnya aplikasi yang mampu memberikan pengguna untuk melakukan interaksi komunikatif. Secara otomatis kegiatan pembelajaran lebih banyak di lakukan di rumah dan melibatkan banyak orang tua wali murid dibandingkan sekolah atau guru sebagai pendidik. Kondisi ini tentunya sangat berdampak dengan peran orang tua dalam membentuk karakter budi pekerti.

\section{METODE PENELITIAN}

Penelitian mencoba mengupas sisi empiris dari sebuah fenomena yang terjadi di tengah masyarakat mengenai kondisi pendidikan di masa Pandemi Covid 19 secara kualitatif dengan tradisi fenomenologi yakni; menangkap kesankesan informatif dari apa yang dilihat, dirasakan, dan dialami oleh peneliti. 


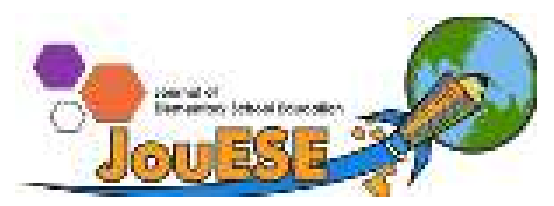

Penelitian dilakukan di Kabupaten Pringsewu Lampung dengan menyebarkan angket dan pertanyaan secara daring menggunakan aplikasi Google Form, WA dan medsos, serta melakukan wawancara secara langsung dengan Orang Tua yang ditemui oleh peneliti. Responden berjumlah 20 sebagai subyek penelitian. Obyek penelitian adalah Respon subyek terhadap pokok kajian yakni pembentukan budi pekerti di sekolah dan pandangan atau saran subyek terhadap pokok kajian. Setelah data didapat maka dianalisis menggunakan teknik analisis domain yakni dengan mencoba membuat pemetaan. Adapun langkah-langkah pelaksanaan penelitian dan pengkajian adalah sebagai berikut:

1) Peneliti melakukan pendalaman mengenai pokok kajian menumbuhkembangkan budi pekerti melalui gerakan penumbuhan budi pekerti di sekolah dasar.

2) Peneliti menyusun angket dan panduan wawancara untuk digunakan dalam pengumpulan data secara daring.

3) Penelitian melakukan wawancara dan menyebarkan angket secara daring.

4) Hasil data secara kualitatif kemudian dianalisis secara domain.

5) Ditarik kesimpulan dari penelitian yang telah dilaksanakan.

\section{HASIL DAN PEMBAHASAN}

A. Respon Orang Tua terhadap Kondisi Pembentukan Budi Pekerti di Masa Pandemi Covid 19

Lingkungan keluarga merupakan suatu lingkungan pertama dan utama dalam menggembleng sikap yang berlandaskan nilai-nilai Budi Pekerti anak sebagai Peserta Didik. Ketika terjadi wabah penyakit menular yang memaksa dilakukan pembatasan sosial berskala besar atau karantina wilayah. Hal tersebut berpengaruh pada pelaksanaan pembelajaran yang akan menghambat kelancaran dan kesuksesan pelaksanaan program pendidikan. Kondisi tentunya akan berdampak pada kuat pada semua pihak yang terlibat dalam pendidikan. Pertanyaan bagaimana Respon Orang Tua dalam menghadapi kondisi ini?. Dari hasil penelusuran peneliti didapat temuan-temuan sebagai berikut

a. Pandangan terhadap Pandemi Covid-19 


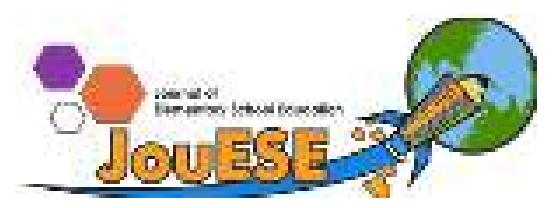

Beberapa orang tua merasa covid-19 merupakan ancaman kesehatan yang serius mengancam kesehatan anak-anak mereka sehingga mereka berpandangan sebaiknya sekolah ditutup dan belajar di rumah.

Namun ada juga orang tua yang menganggap Covid 19 merupakan wabah penyakit biasa seperti wabah penyakit lainnya, bahkan mereka beranggapan pemerintah terlalu membesar-besarkan kondisi ini, sehingga mereka berkeberatan sekolah ditutup.

b. Pandangan terhadap Kegiatan Belajar

Beberapa orang tua merasa senang anaknya senantiasa dekat dengan mereka di rumah ketika masa pembatasan sosial bersekala besar.

Namun sebagian besar orang tua berkeberatan apabila tanggung jawab melakukan kegiatan pembelajaran dilakukan oleh mereka. Mereka telah membayar jasa sekolah dalam mendidik tentunya akan merasa rugi secara ekonomi untuk hal ini. Selain alasan ekonomi, sebagian besar Orang Tua merasa kurang memiliki kemampuan dalam pengajaran dan pembelajaran dibandingkan guru yang memang memiliki latar belakang dalam pengajaran.

c. Pandangan terhadap Gerakan Penumbuhan Budi Pekerti

Sedikit sekali orang tua yang menyatakan bahwa dalam kegiatan menumbuhkembangkan Budi Pekerti tidak ada masalah karena memang mereka telah menjalankan setiap saat baik pada masa normal dahulu, maupun pada masa pandemic covid-19 ini.

Banyak sekali Orang Tua mengeluhkan kesulitan untuk menerapkan pembelajaran Budi Pekerti baik secara oral maupun bentuk-bentuk kegiatan pembiasaan karena dirasakan anaknya terlalu manja, sehingga ia lebih takut dengan guru ketimbang dengan orang tua.

Tidak sedikit Orang Tua yang mengeluhkan ketidakmampuan menggunakan Gawai sebagai media pembelajaran apalagi dipergunakan sebagai penunjang dalam menumbuhkembangkan Budi Pekerti.

B. Pandangan Orang Tua mengenai Gerakan Penumbuhan Budi Pekerti di Sekolah Pada Masa Pandemi Covid 19. 


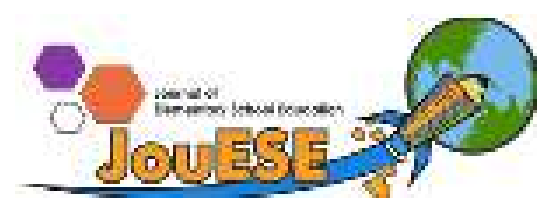

Beberapa orang tua memberikan pandangan kritik, saran dan opini mengenai keberlangsungan program gerakan penumbuhan budi pekerti di sekolah yang tengah mengalami ancaman, hambatan, dan gangguan merebaknya wabah pandemik covid-19 ini.

Berdasarkan hasil penelusuran secara kualitatif berkenaan denga hal tersebut di atas, maka didapat temuan-temuan sebagai berikut:

a. Pengembangan Interaksi Positif antara Peserta Didik dengan Guru

Sebaiknya guru atau pendidik lebih baik lagi menyiapkan fasilitas perangkat lunak pembelajaran guna memberikan pelayanan paripurna pembelajaran.

Guru harus senantiasa intens berkomunikasi dengan siswa secara daring dengan menggunakan Media sosial dan alat komunikasi lainnya.

Guru harus senantiasa memberikan motivasi belajar kepada siswa secara jarak jauh melalui perangkat gawai yang ada.

Guru harus selalu terbuka mendengar keluhan orang tua mengenai kesulitan belajar yang dihadapi anak.

Guru sebaiknya mendampingi orang tua dalam memberikan pengajaran di rumah.

b. Pengembangan Interaksi antara Orang Tua dan Guru

Guru harus selalu melakukan komunikasi intens mengenai kondisi pembelajaran anak kepada orang tua secara intens.

Harus ada pengarahan dari Guru mengenai bagaimana cara melaksanakan pembelajaran di rumah ketika masa Pembatasan sosial.

c. Peran Sekolah dalam Pelaksanaan Pembelajaran

Sekolah diharapkan dapat merancang dan mendesain sistem program pembelajaran daring yang memudahkan, efisien, efektif dan tepat sasaran.

Sekolah diharapkan tidak mengabaikan kewajibannya memberikan pelayanan yang baik dan terpercaya.

Sekolah diharapkan membantu beban orang tua dalam pembiayaan pembelajaran daring dengan membagi beban pembiayaan yang seimbang antara Orang tua dan institusi sekolah dalam hal kegiatan belajar mengajar.

d. Peran serta Masyarakat 


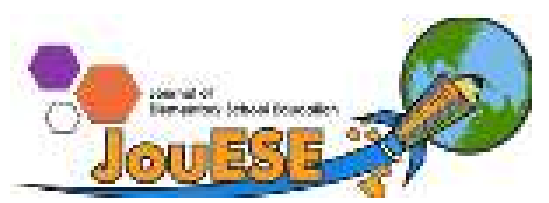

Masyarakat bekerjasama dengan sekolah diharapkan dapat mengakomodasi kegiatan dengan menciptakan lingkungan kondusif bagi keberlangsungan pembelajaran di Sekolah.

Mendorong Masayarakat dan dunia usaha agar bersama-sama berpartisipasi membangun sekolah dengan ikut serta menanggung beban pembiayaan dalam kegiatan pembelajaran daring ini

e. Peran Pemerintah

Orang tua mengharapkan kepada pemerintah agar senantiasa membuat kebijakan yang meringankan beban orang tua dalam pendidikan, terutama berkenaan dengan pembiayaan pendidikan.

Apabila kita sederhanakan uraian mengenai apa saja pandangan orang tua mengenai penumbuhan budi pekerti ini antara lain

1. Harus senantiasa dibangun komunikasi intens antara Guru dan Orang Tua mengenai Bagaimana Menumbuhkembangkan Budi Pekerti secara aplikatif di rumah.

2. Sekolah harus memberikan Layanan Pembelajaran paripurna yang memudah, efisien dan efektif di Masa pandemic Covid-19.

3. Masyarakat harus didayagunakan untuk mendorong dunia usaha memberikan kontribusi kepada keberlangsungan Pendidikan dan Pengajaran di Masa Covid 19 ini.

4. Pemerintah harus mengeluarkan kebijakan yang memberikan kemudahan dan mengurangi beban Orang Tua di masa Covid 19 ini.

\section{SIMPULAN}

Perspektif pandangan orang tua dalam gerakan penumbuhan budi pekerti di Sekolah Dasar pada masa pandemi Covid 19 ini antara lain

1. Orang tua merasa terkejut dan mengalami Culture Shock mengenai perubahan secara tiba-tiba dalam pembelajaran terutama pada penumbuhan budi pekerti. Pembelajaran yang mulanya pelaksanaan dilakukan oleh sekolah lalu menjadi tanggung jawab orang tua. Responnya ada yang bersikap gagap untuk menyikapi, sudah dapat memprediksi, dan masih bingung dengan yang terjadi. 
2. Harapan orang tua adalah semua pihak harus dapat membantu beban yang dihadapi berkenaan dengan pembelajaran, terutama pada guru dan sekolah yang harus senantiasa mendampingi orang tua dalam pelaksanaannya.

\section{DAFTAR PUSTAKA}

Dewi, W. A. F. (2020). Dampak Covid-19 terhadap implementasi pembelajaran daring di Sekolah Dasar. Edukatif: Jurnal Ilmu Pendidikan, 2(1), 55-61.

Herliandry, L. D., Nurhasanah, N., Suban, M. E., \& Kuswanto, H. (2020). Pembelajaran pada masa pandemi covid-19. JTP-Jurnal Teknologi Pendidikan, 22(1), 65-70.

Widiyastuti, R. (2020). Kebaikan Akhlak dan Budi Pekerti. Alprin.

Rahmat, R. (2018). Implementasi Pembelajaran Pendidikan Agama Islam Berlandaskan Nilai-Nilai Karakter Di Sekolah Dasar Laboratorium Universitas Negeri Malang. Tarbiyatuna: Kajian Pendidikan Islam,2(2), $1-18$.

Samal, A. L. (2017). Pentingnya Pendidikan Karakter Dan Budi Pekerti Di Sekolah Pada Era Globalisasi. Potret Pemikiran, 21(2).

Tim Penyusun, (2016). Hands-Out Bahan Pelatian Materi Umum dan Materi Pokok Sekolah Dasar. Jakarta: Direktorat Jendera Pendidikan Dasar dan Menengah Kementrian Pendidikan dan Kebudayaan RI.

Tim Penyusun, (2016). Panduan Pelaksanaan Gerakan Penumbuhan Budi Pekerti Jakarta:Direktorat Jenderal Pendidikan Dasar dan Menengah Kementrian Pendidikan dan Kebudayaan RI. 